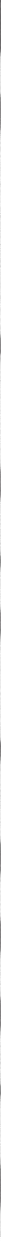

AlBR

Revista de Antropología Iberoamericana

www.aibr.org

Volume 11

Issue 1

January - April 2016

Pages 59 - 76

Madrid: Antropólogos

Iberoamericanos en Red.

ISSN: 1695-9752

E-ISSN: 1578-9705

\section{In Today's World, Anthropology is More Important than Ever}

\section{Maurice Godelier}

École des hautes études en sciences sociales

Received: 20.04.2015

Accepted: 15.12 .2015

DOI: 10.11156/aibr.110104e 


\section{ABSTRACT:}

After the collapse of the European colonialism in the 20th Century, the intellectual Western Word was part of a crisis, which called into questions its own concepts, methods and more fundamentally their legitimacy. The Western World became "another" Western World, and in that context, the discipline, that supposedly explored other societies, experimented a process of deconstruction. On the one hand, this crisis portrays the disappearance of the object of study in the discipline, the "primitive" societies; but on the other hand, it settles down the basis to reconstruct the profession of the anthropologist as a fundamental element in our world. This articles illustrates several examples of the fundamental role that anthropology plays today in the task of serving the scientific interpretation of social diversity. Traditional objects of study in the discipline come back over again and provoke the creation of new and more diverse social groups. This was the case of societies that were formed after the colonial period, including the Baruya, Tikopia, as well as the recent creation of Saudi Arabia.

KEY WORDS:

Anthropology, colonialism, crisis, Western World. 
My first words will be to thank Professor Karl-Heinz Kohl and his colleagues at the Frobenius Institut for their invitation to lecture in this series, entitled "The End of Anthropology". For some of our colleagues, this theme inspires a certain fear; for others, on the contrary, it expresses a hope. For me - and I am not alone - the problem is already behind us.

But whatever our reaction, the question itself grew out of the fact that, for a number of years, beginning somewhere in the 1980s for anthropology and slightly earlier for the literary disciplines, the social sciences and the humanities entered a period of crisis which called into questions their concepts, methods and more fundamentally their legitimacy. Some of our colleagues denied that the work of the anthropologists who had gone before lacked any scientific authority, as did their own work before they became aware of the fictitious and ideological character of the "narrations" constructed by Western anthropologists to disseminate what they claimed to have understood about other forms of culture and society.

The crucial question that anthropology, history, archeology and other social sciences have struggled to answer since the beginning is: How can we come to understand and explain the existence of facts, attitudes and representations that have never been part of our own way of living and thinking?

Obviously this question is not restricted to scientific knowledge alone. It arises each time that, for various reasons, human individuals or groups are brought to interact with other individuals or groups from to different social classes within their own society or from societies profoundly different from their own. Understanding the otherness of others means discovering the meanings and the reasons behind the forms of thought and lifestyles of those who are different from you. It means discovering what relations these others have among themselves, what position they occupy in them and how they represent them. But understanding is not explaining. To explain is to seek to discover how the different social ways of existing we have managed to understand appeared here and there over time and were reproduced - sometimes over several centuries, and sometimes over several millennia - even as they changed, sometimes profoundly, for example the world's great religions - Buddhism, Christianity, Islam.

From Morgan to Lévi-Strauss, from Malinowski to Sahlins, anthropologists have believed that, with the help of their concepts and methods, it was possible to gain knowledge of the social and cultural otherness of others, at a distance, which would therefore be relatively objective. And each believed he was contributing to this in his own 
way. But it was precisely this claim to knowledge and this faith in the methods, concepts and theories developed to achieve it that some of us began in the 1980s to contest, thus setting off a crisis that was far from being wholly negative, as we will see. Why this challenge and the resulting crisis? A look at the context of the 1980s may help answer us understand.

In 1945 Europe emerged victorious from a war with Nazi Germany, fascist Italy and imperialist Japan that had bled it white and made the United States the first world power, ahead of Soviet Russia. It was in this new balance of power that, between 1955 and 1970, the last European colonial empires disappeared, one after the other, either in the wake of bloody wars of liberation or more peacefully. From then on it was no longer possible to say that colonizing meant civilizing and that civilizing meant helping other people advance more quickly on the path towards the progress already achieved by the West. Liberated from direct domination of the European powers, the former colonies and now independent nations took a different path to development. Between 1980 and 1990 another global upheaval occurred, in the form of the accelerated disintegration and then long-awaited collapse of the communist regimes set up after World War Two in central and eastern Europe but also in Asia, the Far East, Africa and in Cuba. Today only a few shreds remain. These two upheavals profoundly modified the West's relations with the rest of the world, but also with itself, and they would go on to shake the intellectual world that grew up in Europe and the United States after the Second World War.

In effect, after the First World War, the Russian revolution appeared to many intellectuals - and not only to intellectuals - as the birth of a new world and a new kind of man, as the next stage in the progress of Humanity. This progress was to consist in doing away with the capitalist economic market, the exploitation of human labor and the wasting of the natural resources that underpinned this system. But it also meant replacing the so-called "bourgeois" forms of democracy serving the owning classes by a higher form of democracy that would serve the people. In short, once again the West - but another West - held itself up as the measure and mirror of Human progress.

It must be recalled here that the West is not singular, but plural, and that it was the West itself that spawned the critique of the economic and political system which gave it its strength. It is therefore understandable that, at the end of the Second World War - in which Stalin's Russia had fought on the side of the Allies and greatly contributed to their victory, before the socialist regimes showed themselves 
for what they were, dictatorships that exploited the masses -the dominant intellectual trends in the social sciences and philosophy, at least in France, were Marxism (Althusser), structuralism (Lévi-Strauss) and existentialism (Sartre). Sartre's position on the inalienable liberty of the individual opposed him to the Marxists and to Lévi-strauss, who argued for the existence of impersonal structures - whether conscious or unconscious - and their structural consequences. In the political arena, however, Sartre rapidly rallied to the partisans of revolution to bring down the bourgeois order.

The successive disappearance of the colonial empires and the socialist regimes shook the European intelligentsia and sparked a crisis that brought us - as Lyotard said - into the "post-modern condition". For Lyotard, this new condition meant two things for thinkers: First it meant the death of all "meta-narratives", in other words of explanations of history and the complex diversity of societies in terms of a first cause and effective in the last analysis, such as the notion of "mode of production" for Marxists or "unconscious structures of the mind" for Lévi-Strauss. And second, the post-modern condition necessarily meant a return to the subject as actor of his history. This was illustrated in France by the second part of Foucault's work, which, after having joined Althusser and Lévi-Strauss in proclaiming the "death of the Subject", he devoted to analyzing the subjectivation of individuals in various institutions structured by relations of power. Having come this far, it seemed clear that the next urgent task of theory was to "deconstruct" - to quote Derrida - all of the former discourses found in philosophy and the social and human sciences.

There is in itself nothing surprising about deconstructing a discipline. It is a necessary and normal moment in the development of all sciences, natural as well as social. It is something that has to be done following the appearance of new ways of interpreting well-known facts or in the face of new facts. But there are two ways to deconstruct a discipline. One leads to its dissolution and eventual disappearance; the other - based on the positive critiques produced during the deconstruction process - paves the way for the reconstruction of this same discipline on new foundations which are more rigorous, more critical and therefore analytically more effective than they were before.

It is therefore indispensable to point out a few of these positive criticisms of anthropology, since they already enable us to begin rebuilding. Furthermore, the very existence of these critiques shows that we must not confuse all of the publications and authors that fly the post-modernist flag. Marcus is not Rabinow; James Clifford is not Crapanzano and 
Stephen Tyler is not Michael Fischer. And none of them were Clifford Geertz, who inspired them. Each is only himself. But before listing some of these results, I feel it is important to show that the theme of "The End of Anthropology" itself falls into the first way of deconstructing a discipline, which leads to its disappearance.

How, in effect, can a scientific discipline disappear? In two ways. A discipline can disappear because its very object ceases to exist, or because, although its object still exists, the discipline that claimed to bring us to know it proved incapable of doing so. Let us take the first hypotheses? Has the object of anthropology disappeared? The Nuer, the Kachin, the Tikiopia and the Baruya have not disappeared. They exist. But their societies, and their ways of living and thinking changed under colonial rule and are still changing. But does a science disappear merely because its objects evolve? In this case, the discipline of history would have ceased to exist long ago, since all of the past societies it studies have either disappeared or still exist but in completely different forms. Perhaps anthropology should disappear then because, for instance, a large portion of Trobriand Islanders live in New Zealand or in Los Angeles. But this implicitly presupposes that anthropology has no object other than so-called "primitive", "traditional", "pre-industrial", "non-urban", or "non-western" societies. In effect, this presupposition is an ideological a priori that anthropology already was already forced to combat at the time of the publication of Morgan's Ancient Society, in which the author divided all known societies into three stages located along a scale of human progress that went from "savage" to "barbaric" to "civilized" - of course represented in his eyes by the European and North American societies, at last liberated from the feudal regimes of the Middle Ages and borne up by the forces of modern market and industrial civilization, and by democracy. The development of urban anthropology, gender studies and medical anthropology show this is far from being the case.

Let us now look at the second reason that might cause the disappearance of our discipline. As we saw, the question asked by anthropology, history and other social sciences is the same: How can we come to understand and explain the existence of what has never been part of our own way of living and thinking? The argument no longer concerns the disappearance of the object of anthropology but the inability of anthropology to exist as a science. According to this reasoning, since it came into being, anthropology has done nothing but produce ethnographic accounts that are no more than the projections of the ideologies of western observers onto the societies the study. Two critical positions 
can be found in this line of thought. The first is that held by George Marcus, who nonetheless tendered the hope of a "New Ethnography"; the second is the radically critical position of Stephen Tyler, who disputes that a new ethnography is even possible. For Marcus and Clifford, the ethnographies written by Malinowski, Leach, Evans-Pritchard and the like were above all "narrative fictions" ${ }^{1}$ written with the complicity of the two parties engaged in getting to know another society - the ethnologist and his informants- and in producing "fictions that each side accepts". ${ }^{2}$ Marcus, however, believes that we can do otherwise and better. For Stephen Tyler, on the other hand, all ethnographic accounts are fated to be merely a "reality fantasy of a fantasy reality". ${ }^{3}$ In his opinion, anthropology as a science was still-born, for any ethnographic account is "neither an object to be represented nor the representation of an object ... no object of any kind precedes and constrains ethnography. Ethnography creates its own objects in its unfolding and the reader supplies the rest". ${ }^{4}$ Here we recognize the theoretical position of Derrida and Paul de Man, for whom it was mandatory to "deconstruct the illusion of reference, the possibility that a text could refer to a non-textual reality". ${ }^{5}$ Yet it is difficult to believe that the events and practices of other societies reported by anthropologists were all hallucinations (a fantasy reality) and that, for example, the attacks of September 11, 2001, claimed by Bin Laden and Al Qaeda were no more than a TV show (a reality fantasy).

I see that most of these criticisms bear on a single aspect of the anthropologist's trade, on the moment the anthropologist attempts to give a written account of his fieldwork and subsequent analyses. Clifford's criticism of ethnological monographs is at odds with reality. Indeed an ethnographic monograph is not a literary work (though it may have literary qualities), and there are two reasons for this. Unlike Macbeth, a character sprung from the mind of Shakespeare, the Kula existed before Malinowski landed in Kiriwina and continued to exist after he left. The second reason is that no one can complete or refute

1. James Clifford, "De l'ethnographie comme fiction. Conrad et Malinowski”, Etudes rurales, 1985, pp. 97-98.

2. George Marcus, Ethnography through Thick and Thin (Princeton, Princeton University Press, 1998), p. 110

3. Stephen Tyler, "From document of the occult to occult document", in J. Clifford and George Marcus, Writing Culture. The Poetics and Politics of Ethnography (Berkeley, University of California Press, 1986), p. 139.

4. Tyler, ibid., p. 131.

5. Paul de Man, The Resistance to Theory (Minneapolis, University of Minnesota Press, 1986), pp. 19-20. 
Shakespeare's work, whereas the studies carried out by Fred Damon, Nancy Munn, Annette Weiner and others, fifty years after Malinowski, completed, enriched and corrected his analysis of the Kula. By contrast, curiously enough, there are two essential moments in the anthropologist's trade that have not been the object of fundamental criticism. The time in the field known as "participant observation", and the time when the anthropologist sits down to work out the interpretation of his or her fieldnotes, a time that begins in the field but continues beyond. Perhaps these omissions can be attributed to the fact that James Clifford, who was so critical of the ways others had of "writing culture" never conducted fieldwork himself. But let us leave Tyler's provocations or Marcus' exaggerations and return to a few positive yielded by the critiques of our "post-modern" colleagues.

One very important result is to have pointed out the absence - or near absence - in the publications of numerous anthropologists of any analysis of the colonial relations inflicted on the populations even as they were carrying out their fieldwork. Evans-Pritchard, for example hardly alludes to the presence of British troops having arrived to subdue the tribes around where he was working. That does not necessarily mean that Evans-Pritchard was an agent of colonialism, nor that what he wrote about Nuer kinship and the political structures was false. Nor have all anthropologists passed over the colonial context of their work in silence. Take for example Firth, who is clear about what was happening in Tikopia, or, in France, Germaine Tillion, who worked in Algeria at the height of the colonial war, which she criticized publicly. Anthropologists were also right to point to the presuppositions contained in the notions of "progress" and "civilization", especially since the western ideology of progress is not dead. It has simply mutated into the ideology of Human Rights, which provides Westerners and their allies with new reasons to judge other societies and to interfere in their development. On all these points, Subaltern and Post-colonial Studies have picked up where the first critiques left off, and they have made a considerable contribution. ${ }^{6}$

Another important point was the appeal launched by George Marcus and others that anthropology publishing speak with a plurality of voices and not only that of the anthropologist. Of course there was a risk that all of these voices would then be claimed to be equally valid

6. David Ludden (ed), Reading Subaltern Studies: Critical History, Contested Meaning and the Globalization of South Asia (New Delhi, Parmanent Black, 2001). For a critical overview, see J. Pouchepadass, “Que reste-t-il des Subaltern Studies?”, Critique internationale, $\mathrm{n}^{\circ} 24$, 2004, pp. 67-79. 
and that the anthropologist would have nothing specific to add that would give him any particular weight in this concert. Other critiques arose not from the changing balance of power and interests between the West and the rest of the world, but from the struggles occurring within the western countries themselves, which also contributed to showing the work of our forbears in another light. I am talking about the criticisms - which developed first in the United states and the other AngloSaxon countries - of all forms of discrimination, segregation and exclusion found in our societies, but also in the rest of the world for reasons of sex, skin color, religion, etc. These forms of discrimination are not necessarily perceived as such in other societies, for example in Islam, where the fact that women are subordinated to men is considered to be grounded in their religion. In the West, such views are now criticized in the name of the idea of the equality of all human beings before the law. This is an idea that was certainly not present at the beginning of social life in caste-based India, in the Islamic world, in Baruya society and is still not accepted in many aspects of European social life. James Clifford $^{7}$ made a useful contribution on this point when he showed that, in the otherwise remarkable book by Godfrey Lienhardt, Divinity and Experience. The Religion of the Dinka, ${ }^{8}$ women did not appear, except for one occasion when a women explained to the anthropologist what cattle meant to men. This is probably a case of androcentrism, but it is also notoriously difficult in certain societies for a male anthropologist to enter into contact with women.

A final point in this retrospective of positive contributions made by post-modern criticism. Post-modernists have strongly contributed to the rejection of any essentialist interpretation of the otherness of others. This is not a new criticism. In the first decade of the twentieth century, Boas had already shown that Northwest American Indian societies were open to and borrowed from each other: they were by no means totalities closed in around their essence. Which is not to say that there are not dominant aspects of culture and organization in all societies that are borne by their members as chief components of their identity and experienced as such. And it is easily understood that these dominant aspects do not vanish in a day, since they are largely responsible for the very reproduction of these societies.

In short, there is nothing in all of these criticisms to indicate that we are going through, what Sahlins calls the "the twilight of anthropology". The conclusion is clear. We must keep on deconstructing, but so as

7. James Clifford, "Partial truths", in J. Clifford and G. Marcus (eds).

8. G. Lienhardt (Oxford, Oxford University Press, 1961). 
to reconstruct on foundations better equipped to meet the challenges of the globalized world in which we will live and work in the twenty-first century.

I would like to spend the rest of this lecture on the question I raised at the outset: How can we come to understand the otherness of others? and to show how and why I believe anthropology is better able than it was in the past to provide an answer, but on certain conditions. First, the social and historical otherness of others must be relative and not absolute. Next, others must be capable of understanding that which humans invented for the purpose of interpreting the world around them and themselves within this world, and therefore for the purpose of acting on the world as well as on themselves - whether it be the Aboriginal "Dreamtime", Mahayana Buddhism or Marxism. It is also essential to stress that, while humans can understand the social otherness of other humans, they are not obliged to espouse the principles and values that produced this otherness, nor are they obliged to practice them themselves. Anyone can verify in his own experience of others that these two conditions exist in a very real way and that they invalidate the theses of those who argue for a fundamental incommunicability between cultures. To be an anthropologist is to exercise a profession that entails the production of verifiable and therefore refutable knowledge; the anthropologist's aim and methods are not those of the missionary, the soldier or the merchant, who intervene in societies that are not theirs. And to exercise his profession, it is not enough that the otherness of others be knowable, the anthropologist has to have acquired the means to learn about this otherness.

For that, he must begin by constructing his own Cognitive Ego, which is different from his Social Ego and his Intimate Ego. The Social Ego can be inherited from birth - one is the son or the daughter of a Brahmin, for example - or constructed over the course of a lifetime. The Intimate Ego is fashioned from birth by pleasant or painful encounters with others. This is the Ego of desires, pleasures and sufferings, the Ego that fashions a sensibility; it is also a way of being with others. Of course the Social Ego and the Intimate Ego are inextricably intertwined, and in this the anthropologist is no different from other people. What distinguishes the anthropologist is that he must construct yet another Ego, a Cognitive Ego. The Cognitive Ego is first of all an Intellectual Ego that is put together before leaving for the field from mental components concepts, theories, discussions, controversies - acquired at the university or elsewhere and which bear the mark of their time. At one time one is readily a structuralist, at another a post-structuralist. But whatever the 
epoch, the Cognitive Ego is an Ego which must learn to decenter itself with respect to the other Egos. But the Cognitive Ego is at the same time an Ethical and Political Ego that must maintain a state of critical vigilance against the ever-possible intrusion of judgments his own society has already formulated about other societies. To decenter oneself is also to suspend one's own judgment, to push back to the very horizon of consciousness the presuppositions of one's own culture and society, including those of one's own life story.

But the Cognitive Ego is not made up of ideas alone. The anthropologist must engage in a practice called "participant observation", in the course of which he immerses himself in another society or another social milieu so as to study and understand them. But this raises a formidable problem that has remained unspoken in the criticisms addressed to anthropology. What does it mean to "observe" and to observe while "participating", and what is one supposed to participate in and to what extent? Participating in the life of others is not at all the same thing as going hunting a few times with a group of Inuit and on those days helping feed oneself and others. To claim to be really "participating" in the life of others, the anthropologist would have to "behave like the others", to marry into the society, to have children and raise them, to take part in their rites. The great majority of anthropologists do not do this, and it is not necessary for them to do so in order to understand the ways those with whom they live think and act. There is a fundamental difference between the anthropologist and those with whom he lives when it comes to how he uses what he gradually learns about the principles guiding their thinking and acting. For the members of the surrounding society, the knowledge they have of their myths, their rites, their kinship rules, the habits of the game they hunt, etc. serves to produce their concrete conditions of existence and thereby to reproduce - up to a certain point - their society. This goes on day in and day out. While for the anthropologists, this knowledge he has worked so hard to acquire and which is never complete, almost never serves to produce the concrete conditions of his own existence in the society in which he has immersed himself. To be sure it serves to understand others, but not to act and interact as they do on all occasions. For as he accumulates this knowledge, the anthropologist at the same time produces himself as an anthropologist, and this is a status that endows him with a position in his own society. This sheds some light on the nature of the place the anthropologist occupies when he is in the field. It is a place that he must construct, and this is difficult: it is a place that puts him at the same time outside and inside his own society, but also inside and at the same 
time outside the society in which he has chosen to live. This place is thus at once concrete and abstract, which makes the presence and the work of the anthropologist an original experience of the relationship a man or a woman can have with others and with him or herself.

Whatever the limits of his participation in the life of others may be, it is in this context that the anthropologist observes them. But just what does he observe? In principle all of the interactions that go on around him, in the most diverse concrete situations, between the individuals and groups that make up the society in which he has chosen to live and work. To be sure he does not observe the whole society, but his field of observation is structured by several kinds of events, which are most enlightening. Certain recurring and predictable events are continually offered to his observing gaze: people get up, eat, go hunting or into the fields, come home, go to bed, etc. Other events occur that are not repetitive but which are up to a certain point predictable - a hunting accident, a murder and its aftermath, etc. Last of all there are cyclical events that come around again after several years and which concern all members of the society the Baruya's male and female initiations, for instance. And yet, alongside these events that are in a way offered up for observation, the anthropologist also has to make use of observations that he has prompted by launching systematic large-scale studies and surveys, which can last for months and bear on different aspects of the social life of others - their agricultural practices, their initiation rites, forms of land-holding, land use and use of the territory. When the field data are crossed, they produce results and discoveries that often surprise the anthropologist and contribute to giving him an even better understanding of the logic behind the ways the people around him think and act.

When these observations have been gathered - something that can take years - they must be interpreted and then diffused. The anthropologist must then move on to other forms and levels of work. He must, for example, compare his data with that gathered by anthropologists in other societies. For instance, when I realized that the Baruya used an Iroquois-type kinship terminology - and since I knew that the same type of terminology in Iroquois society was associated with a matrilineal descent rule, whereas in Baruya society it is associated with a patrilineal descent rule - I was led to ask myself some theoretical questions concerning the conditions in which Iroquois-type kinship systems appeared and how they came to be distributed over several continents. ${ }^{9}$ These theoretical questions came to me, but they were of no interest

9. Maurice Godelier, Métamorphoses de la Parenté (Paris, Fayard, 2004). 
to the Baruya. Of what practical use would it be to the Baruya to know that they have the same kinship terminology as certain Indians in North America? It might have interested some of the Baruya who had already been to university, or were interested in the European or other societies. But aside from a very limited impact, this anthropological concern - entirely legitimate from the standpoint of the effort to learn about human modes of existence - does not mesh with any of the Baruya's existential problems.

This analysis of the difference between the knowledge shared by the actors themselves and that possessed by the anthropologist makes it clear that, for the actors, this concrete knowledge is an existential truth, whereas for the anthropologist, it is abstract knowledge that will become the material he will use to try to construct some scientific truths. The discovery that the Baruya have a patrilinear kinship system which uses an Iroquois-type terminology allows us to understand how and why the notions of mother, father sister, brother or cousin are different for them than for someone from the West. In effect, if all of my father's brothers are also my fathers, and if all of my mother's sisters are my mothers, if all of their children are my brothers and sisters, then when my mother's husband dies, I still have other fathers. And if I do not have a sister to give in exchange for a wife, I have the right and therefore the possibility to exchange my father's brothers' daughters because they too are my sisters. Confronted with any number of problems, the Baruya has at his disposal, by the very nature of his kinship system, a network of solidarity and mutual assistance that we do not have. And that is something the anthropologist can observe and verify.

However much these essential truths may differ from one society to the next, they are nevertheless all attempts to answer existential questions, which, on the contrary, are present in all societies, although in specific forms. Humans, always and everywhere, have endeavored to understand what it means to be born, to live and to die. Everywhere they have thought about the kinds of power they could legitimately wield over themselves or over others. Everywhere they have been concerned to define the relations humans are supposed to have with their ancestors, with nature spirits, with the gods or with God. Everywhere they have been concerned to give meaning to their environment - mountains, forest, sea, etc. And everywhere they have assigned a sense to the inequalities they established between the sexes, between the castes, and so on, whether in order to legitimize it or to challenge it. In short, one of the objects of anthropology - and of history in fact - is to compare these cultural and social answers and to explain, if possible, the conditions of their appear- 
ance and disappearance over space and time. These are levels of the theoretical work which go beyond the anthropologist's singular experience of a society in the field.

To conclude, I would like to use my personal experience to illustrate what I have learned from my efforts to deconstruct and reconstruct anthropology. When I undertook to deconstruct a few self-evident anthropological truths, I came to realize that some of theses celebrated truths were now dead for me. I showed that nowhere are kinship relations, and even less the family, the basis of societies. This conclusion is valid for all societies, even those without classes or castes - which seemed to be proof to the contrary - and which the textbooks called "kin-based societies".

When I began researching kinship systems and their past or recent metamorphoses, I also looked at an aspect usually left to one side: the way societies, in accordance with their kinship systems and their descent rules - unilineal, bilineal or undifferentiated - represent the way children are made, from the time of their conception. I therefore compared the representations found in twenty-two societies in Oceania, Africa, Asia and North America as well as the European Christian view. To my great surprise, I found that all of these societies, despite their different kinship systems, had one point in common: all, in one form or another, maintained that sexual intercourse between a man and a woman was not enough to make a child. What they made with their semen (the Baruya) or with their menstrual blood (the Trobriand Islanders) was a fetus; but for this fetus to become a child it always took the intervention of other invisible and more powerful agents ancestors who reincarnated in the child's body (Inuit, Trobriander) or the Christian God who at the time of his choosing introduced a soul into the child's body.

In other circumstances I was led to re-examine Mauss' famous analysis of the Gift, revisited and criticized by Lévi-Strauss. In the process, I discovered that, alongside things one sells and those one gives, there are also things that Mauss and Lévi-Strauss neglected to analyze; these are things that must be neither sold nor given, but must be kept and passed on. This third category of "things" always bears a major aspect of the identity of human groups. They belong to what we call the domain of the "sacred", but we must be careful here: the sacred extends beyond the religious domain to include the political. In our democratic societies, the Constitution, which sets down the rules that enable millions of people to live together, is an object that can be neither sold nor bought. What can be bought are electoral votes, but not 
the Constitution itself, which is not a commodity. The existence of this area of life which does not fall into the category of commercial exchanges, nor that of exchanges of gifts and counter-gifts - equivalent or not - shows the limits of Lévi-Strauss' (and others') claim that social life rests entirely on exchange: the exchange of women, of wealth and services, of signs and of meanings - in other words, kinship, economy and culture. In fact, they had simply forgotten that, in order for things to be exchanged and to circulate, there had to be other things that did not circulate and were not for exchange.

These analyses then led me to raise two problems, which turned out to be connected. One was the presence and the role at the heart of all social relations of imaginary cores. An example from kinship: Patrilineal societies claim that the man's semen makes the body of the fetus and that the woman is a mere vessel for this semen. Or, on the contrary, Trobriand Islanders maintain that the semen does not make the body of the fetus, which is the job of the mother's menstrual blood. The Baruya claim that it was the Sun who gave the ancestor of the Kwarrandiar clan the "Kwaimatnie" - the sacred objects and secret formulas that allow them to initiate their boys and make them into warriors .

Of course, all these stories refer to facts - which we regard as imaginary - and are enacted in the initiation rites that constitute symbolic practices which transmute imaginary facts into real social relations in which individuals occupy distinct but interconnected positions according to sex, age, or their capacity to become great warriors or shamans. Contrary to Lévi-Strauss, but in line with Geertz, what we are looking at here is not the primacy of the symbolic but the primacy of the imaginary by means of the symbolic.

The Baruya case raised another problem but at the same time suggested an answer. According to Baruya tradition, their society appeared recently, somewhere around the eighteenth century, according to my calculations. It originated with a group of men and women from several clans of one tribe, the Yoyué, who, fleeing a massacre, had found refuge and succor with the Andjé, a tribe living a few days' walk away. Several generations later, the refugees' descendants massacred their hosts and took over part of their territory, where they built their own initiation house and initiated their own boys. In this case it is clear that it was neither the kinship relations nor the economic relations between individuals and groups that made them a society. It was what we in the West call political-religious relations: "religious" because, in the course of the initiations, the gods and the ancestors work together with the initiation masters to initiate the boys; "political" because the initiations are believed to 
cleanse the boys of what they received from women and prepare them to govern their society without them. In short, it is these political-religious relations that establish and legitimize the sovereignty the Baruya exercise over their territory, whose boundaries are known if not recognized by the neighboring tribes.

We will pass over the example of Tikopia, according to the traditions reported by Firth, was invaded by groups from other islands - Ontong Java, Pukapuka, Rotuma, Anuta, etc. - which engaged in constant battles until the clan ancestor of the Kafika instituted rites in which each group had its function and place and which made them into a society. The founding ancestor having been assassinated by a rival, the gods of Polynesia changed him into an atua, god of the Island of Tikopia, and his direct descendants thus came to have first place in the rites, because their bodies now possessed the mana of a god. In Tikopia, too, then it was political-religious relations that welded the various non-related human groups into a society. ${ }^{10}$

A last example will bring us up to the present century and to the globalized world in which we will now be practicing our trade. Saudi Arabia is a state that did not exist at the beginning of the eighteenth century. It arose between 1740 and 1742 from the joint ambitions of two men: Mohammed Abd al Wahhab and Mohammed Ibn Saoud. The first was a religious reformer and member of a tribal confederation that had expelled him when he called for a Jihad against what he considered to be the bad Muslims that populated the holy places of Islam - Mecca and Medina. In the same vein as Hanbalism, one of the four schools of law within Sunni Islam, which appeared in the ninth century, Mohammed Abd al Wahhab was opposed to all innovation, all personal interpretation of the Koran, and wanted to force all Muslims to return to the traditions of the early believers. The other, Mohammed Ibn Saoud, an ambitious tribal chief and ruler of the small Nadj city of al-Dir'iya in central Arabia, aspired to bring all of the surrounding tribes under his rule as well. But in the Muslim world this also required religious legitimacy. This was provided by the preacher Mohammed Abd al Wahhab with his call to Jihad, for which he needed the support of a political and military force. The meeting between the two men resulted in the alliance of two types of social power - religious and political - and in the birth of the first Saudi state and the taking in 1802-1804 of Mecca and Medina. At that time Wahhabism became the state religion. ${ }^{11}$

10. Raymond Firth, Tikopia Ritual and Belief (Boston, Beacon Press, 1967), pp. 15-30. 11. Madawi Al-Rasheed, A History of Saudi Arabia (Cambridge, Cambridge University Press, 2002); Alexei Vassiliev, The History of Saudi Arabia (London Saqi Books, 2002). 
Now let us fast-forward a century and a half. In 1938 oil was discovered in Saudi Arabia, which found itself in possession of a quarter of the world's reserves. In 1945, Franklin Roosevelt signed a treaty with the Saudi king in which the United States promised to defend the kingdom against neighboring Iraq and Iran in exchange for its oil. In 1979, under Ayatollah Khomeini, Iran with Shi'a Islam as its official religion, became the first Islamic republic, and the Russians invaded Afghanistan. Thousands of Muslim volunteers, among whom Bin Laden, armed by the Americans and funded by Saudi Arabia, spent a decade battling the Russian army, forcing them to withdraw from Afghanistan in 1989. After the Russians' departure came the Taliban and Al Queda ("the Base"), which was created to launch the Jihad no longer only against bad Muslims, as in the eighteenth century, but against Jews, Christians and in general against the materialistic West that had been humiliating and exploiting Arabs and Muslims since the nineteenth century.

Once again neither kinship relations nor economic relations explain the formation of this new society. The economy of the eighteenth-century central Arabian tribes did not in itself drive the formation of a state, no more than did the kinship relations found in the tribes or tribal confederations - although once the state began to take shape, marriages and alliances between the great "houses" and tribes bolstered the power of the Saoud dynasty. ${ }^{12}$

That is where we stand today. After $9 / 11$, which once again upset the balance of power in the world, we saw the US fail in their intervention in Iraq and lose their global political hegemony. Other peoples and other nations - China, India, Russia - are now bringing their own influence to bear on relations between the West and the rest of the world, though this may not mean the death of capitalism but rather a new opportunity for a multitude of local societies to re-affirm or re-invent their cultural and political identities. As economies find themselves every more closely integrated into the capitalist market system, an opposite trend is prompting the segmentation of political regimes and resistance from local identities.

Nothing in this process seems to predict the approaching death of anthropology. On the contrary, anthropology - together with history - is one of the social science disciplines best able to help us understand the complexity of our now globalized world and the nature of the conflicts and crisis we are experiencing. In such a world, it would be irresponsible

12. Maurice Godelier, Au fondement des sociétés humaines: Ce que nous apprend l'anthropologie (Paris, Albin Michel, 2007), pp. 221-248. 
and indecent for anthropologists stop trying to understand others - and themselves at the same time - and making their results known. After all, that is our job.

Thank you for your attention.

\section{Paris, 11 May 2008 Translated by Nora Scott}

\section{References}

Al-Rasheed, M. (2002). . Cambridge: Cambridge University Press.

Clifford, J. (1985). De l'ethnographie comme fiction. Conrad et Malinowski. 97-98.

Clifford, J. (1986). Partial Truths. En J. Clifford and G. Marcus, Eds.

De Man, P. (1986). Minneapolis: University of Minnesota Press.

Firth, R. (1967). . Boston: Beacon Press.

Godelier, M. (2004). . Paris: Fayard.

Godelier, M. (2007). Au Fondement des Sociétés Humaines: Ce que nous apprend l'Anthropologie. Paris: Albin Michel.

Lienhardt, G. (1961). Oxford: Oxford University Press.

Ludden, D. (Ed.) (2001). Reading Subaltern Studies: Critical History, Contested Meaning and the Globalization of South Asia. New Delhi: Parmanent Black.

Pouchepadass, J. (2004). Que reste-t-il des Subaltern Studies? : 67-79.

Marcus, G. (1988). Princeton: Princeton University Press.

Tyler, S. (1986). From Document of the Occult to Occult Document. En J. Clifford y G. Marcus. Berkeley: University of California Press.

Vassiliev, A. (2002). . London: Saqi Books. 